\title{
Chronic Inflammatory Gingival Enlargement and Treatment: A Case Report
}

\author{
Mehmet Özgöz ${ }^{1 *}$ and Taner Arabaci ${ }^{2}$ \\ ${ }^{1}$ Department of Periodontology, Akdeniz University, Turkey \\ ${ }^{2}$ Department of Periodontology, Atatürk University, Turkey
}

Submission: June 14, 2018; Published: July 18, 2018

*Corresponding author: Özgöz, Department of Periodontology, Akdeniz University Faculty of Dentistry, Antalya, Turkey, Fax:+902423106967;

Email:mehmetozgoz@hotmail.com

\section{Abstract}

Gingival enlargement is a common feature in gingival disease. If gingival enlargement isn't treated, it may some aesthetic problems, plaque accumulation, gingival bleeding, and periodontitis. In this paper, inflammatory gingival enlargement and treatment was presented.

Keywords: Gingival enlargement; Periodontal treatments; Etiological factors; Plasma cell gingivitis

\section{Introduction}

Gingival enlargement is a common feature in gingival disease $[1,2]$. Many types of gingival enlargement can be classified in connection with etiological factors and pathological changes [3-5].

a) Inflammatory enlargement: chronic and acute [6].

b) Drug-induced enlargement [7-12].

c) Gingival enlargements associated with systemic diseases:

i. $\quad$ Conditioned enlargement (pregnancy, puberty, vitamin $\mathrm{C}$ deficiency, plasma cell gingivitis, non-specific conditioned enlargement-granuloma pyogenicum).

ii. Systemic diseases causing gingival enlargement (leukemia and granulomatous diseases -Wegener's granulomatosis, sarcoidosis, etc. [13-15].

d) Neoplastic enlargement (gingival tumors) - benign tumors and malignant tumors.

e) False enlargement - these enlargements are not real enlargements but may appear as such because of increase in size of the underlying osseous or dental tissue. The gingival tissue usually has no clinical signs of inflammation $[16,17]$.

Chronic inflammatory gingival enlargement originates as a slight ballooning of the interdental papilla and/or the marginal gingiva. The enlargement is generally papillary or marginal and may be localized or generalized. It progresses slowly and painlessly unless it is complicated by acute infection or trauma. Chronic inflammatory gingival enlargement is caused by prolonged exposure to dental plaque. Factors that favor plaque accumulation and retention include poor oral hygiene, abnormal relationship of adjacent teeth, lack of tooth function, cervical cavities, improperly contoured dental restorations, food impaction, nasal obstruction, orthodontic therapy involving repositioning of the teeth, and habits such as mouth breathing and pressing the tongue against the gingival [18-20].

Overgrowth of the gingival tissue makes it more difficult for patients to maintain oral hygiene [9,21]. Surgical correction of the gingival overgrowth is still the most frequent treatment. Such treatment is only advocated when the overgrowth is severe. It includes scalpel gingivectomy, overgrowth flap surgery, electrosurgery and laser excision [22]. The aim of this paper is to present chronic inflammatory gingival enlargement and its treatment.

\section{Case Report}

A 35-year-old female patient came to Atatürk University, Department of Periodontology complaining of the gingival enlargement and bleeding.Clinical examination revealed gingival enlargement between upper left and right first incisors (Figure 1). The enlarged gingiva was edematous and susceptible to bleeding when probed. First, intensive dental plaque control procedures and scaling and root planning was applied. Extirpated tissue pattern was sent to histological analysis. The histological analysis showed collagen accumulation in the gingival tissue and the presence of chronic inflammation. After this procedure the patient received oral hygiene advice and was reviewed to check healing. One week later, there is no plaque accumulation, but gingival enlargement is continuing. A decision was made to remove the gingival enlargement by scalpel gingivectomy. Gingivectomy 
procedure was applied to the affected area. The patient was reviewed to check healing. After one week reviewed the operative area irrigated (Figure 2). The patient was reviewed every three months for one year. The post-operative follow-up wasn't eventful.

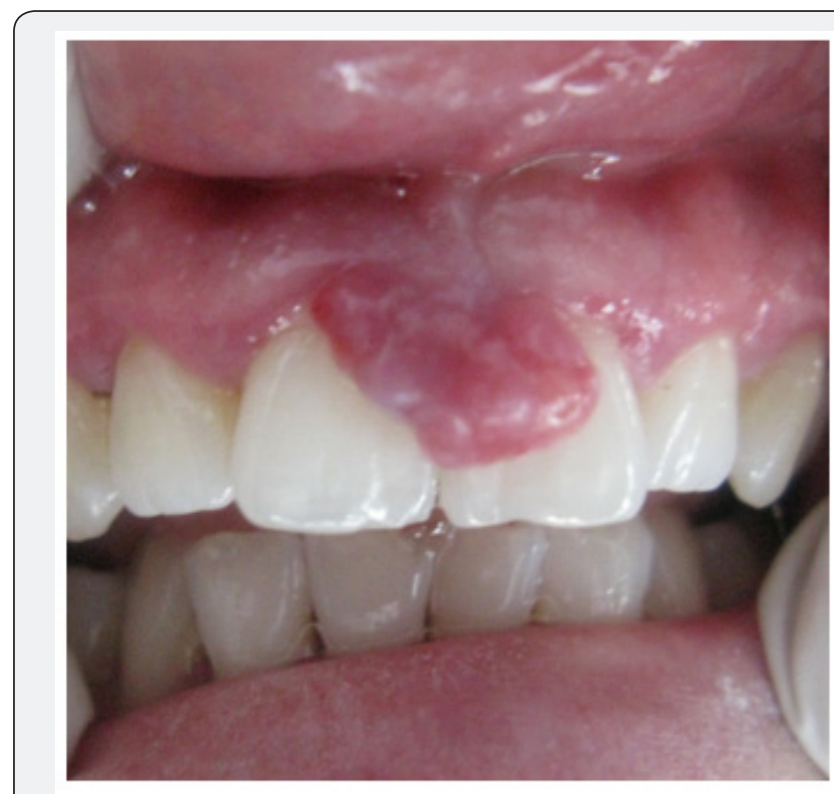

Figure 1: Appearance of gingival enlargement between upper left and right first incisors.

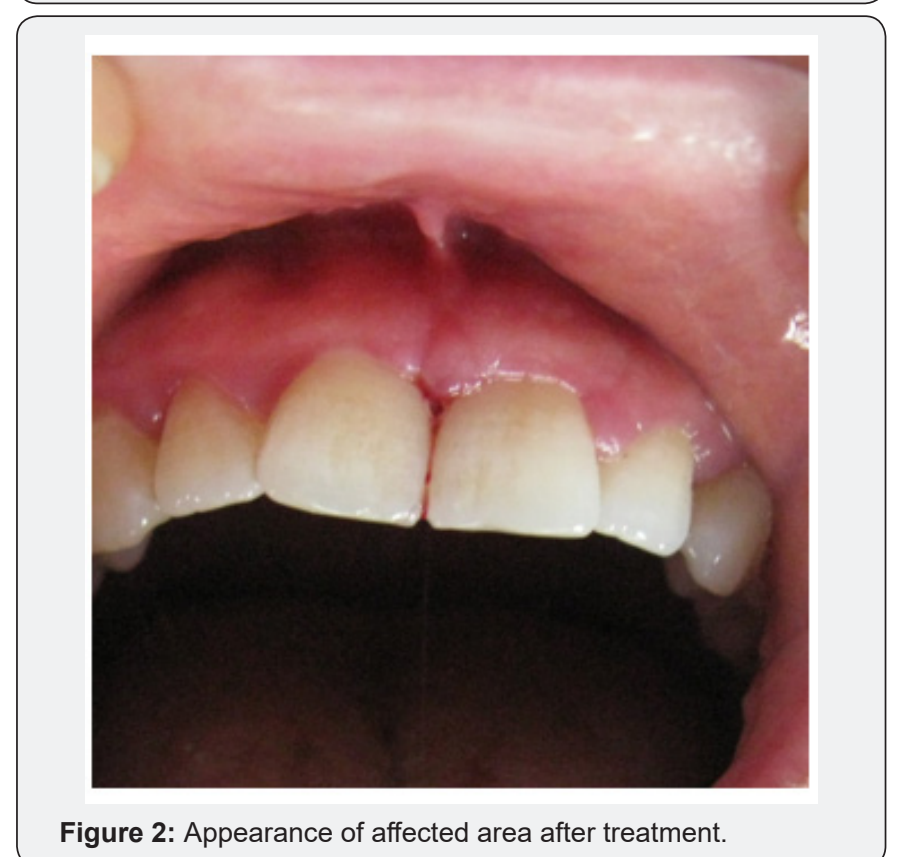

\section{Discussion}

Gingival enlargement is a common feature in gingival disease $[1,2]$. It can develop from chronic or acute inflammatory changes. Inflammatory gingival enlargement is usually secondary complication of other types of enlargement, and together they are called combined gingival enlargement [23]. Treatment of gingival enlargement is based on an understanding of the cause of enlargement and the underlying pathologic changes $[3-5,18]$.
Enlargements resulting from inflammation alone can be treated successfully with local procedures, and fastidious oral hygiene prevents recurrence. When systemic or unknown conditions are partially, or entirely responsible, surgical removal can eliminate the enlargement. Two techniques are available for this purpose: gingivectomy and flap operation [18]. Selection of the appropriate technique depends on the size of the enlargement and the character of the tissue. When the enlarged gingiva remains soft and friable even after scaling and root planning, gingivectomy is used to remove it, because a flap requires firmer tissue to adequately perform the incision and other steps in the technique [18]. In this case we performed gingivectomy technique.

\section{Conclusion}

If we want to treat gingival problems and avoid complications of periodontal therapy, it is necessary to have good knowledge of the cause of enlargement and the underlying pathologic changes and periodontal therapy techniques.

\section{References}

1. Beyer DJ, Belsito DV (1997) Delayed hypersensitivity to silicon causing gingival hyperplasia. Contact Dermatitis 37(5): 234-235.

2. Armitage GC (2004) Periodontal diagnoses and classification of periodontal diseases. Periodontol 2000 34: 9-21.

3. Seymour RA, Ellis JS, Thomason JM (2000) Risk factors for druginduced gingival overgrowth. J Clin Periodontol27(4): 217-223.

4. Rees TD (1999) Disorders affecting the periodontium. Periodontol 2000 21: 145-149.

5. Somacarrera ML, Hernandez G, Acero J, Moskow BS (1994)Factors related to the incidence and severity of cyclosporine-induced gingival overgrowth in transplant patients. A longitudinal study. J Periodontol 65(7): 671-675.

6. Majola MP, McFayden ML, Connolly C, Nair YP, Govender M,et al. (2000) Factors influencing phenytoin-induced gingival enlargement. J Clin Periodontol27(7): 506-512.

7. Nishikawa S, Nagata T, Morisaki I, Oka T, Ishida H (1996) Pathogenesis of drug-induced gingival overgrowth. A review of studies in the rat model. J Periodontol 67(5): 463-471.

8. Seymour RA (2006) Effects of medications on the periodontal tissues in health and disease. Periodontol 2000 40: 120-129.

9. Brunet L, Miranda J, Farre M, Berini L, Mendieta C (1996) Gingival enlargement induced by drugs. Drug Saf 15(3): 219-231.

10. Aimetti M, Romano F, Debernardi C (2005) Effectiveness of periodontal therapy on the severity of cyclosporine A-induced gingival over growth. J Clin Peridontol32(8): 846-850.

11. Embery G, Waddington RJ, Hall RC, Last KS (2000) Connective tissue elements as diagnostic aids in periodontology. Periodontol 2000 24(1):193-214.

12. Rees TD (1998) Drugs and oral disorders. Periodontol 2000 18: 21-36.

13. Buckley DJ, Barrett AP, Bilous AM, Despas PJ (1987) Wegener's granulomatosis - are gingival changes pathognomonic? J Oral Med42: 169-172.

14. Gonzales TS, Colema GC (1999) Periodontal manifestations of collagen vascular disorders. Periodontol 2000 21: 94-105.

15. Lee W, O'Donnell D (2003) Severe gingival hyperplasia in a child with I-cell disease. Int J Paediatr Dent13(1): 41-45. 
16. Wright JM (1999) Reactive, dysplastic and neoplastic conditions of periodontal ligament origin. Periodontol 2000 21: 7-15.

17. Khorsandian G, Lapointe HJ, Armstrong JEA, Wysocki GP (2001) Idiopathic noncondylarhemimandibular hyperplasia. Int J Paediatr Dent11(4): 298-303.

18. Carranza FA (1996) Gingival enlargement. In:Carranza FA (Ed.), Glickman's clinical perodontolgy. $\left(8^{\text {th }} e d n\right)$, WB Saunders Co. Philadelphia, London, Toronto, Montreal, Sydney, Tokyo.

19. Fu E, Nieh S, Chang HL, Wang S(1995) Dose-dependent gingival overgrowth induced by cylosporin in rats. J Periodontol 66(7): 594598.

This work is licensed under Creative Commons Attribution 4.0 License DOI: 10.19080/ADOH.2018.09.555766
20. Grant DA, Stern IB, Listgarten MA (1988) Gingival enlargement: hyperplastic and inflammatory enlargement. In: Grant DA, Stern IB, Lisgarten MA (Eds.),Periodontics in the tradition of Gottlieb and Orban. The Mosby Co. St. Louis, Washington, Toronto.

21. Prisant LM, Herman W (2002) Calcium channel blocker induced gingival overgrowth. J Clin Hypertens 4(4): 310-311.

22. Mavrogiannis M, Ellis JS, Thomason JM, Seymour RA (2006) The management of drug-induced gingival overgrowth. J Clin Periodontol33(3): 434-439.

23. Kesić L, Mihailović D, Pesić Z, Obradović R (2008) False gingival enlargement as a diagnostic problem: a case report. Int J Dent Hygiene6(1): 68-71.

\section{Your next submission with Juniper Publishers will reach you the below assets}

- Quality Editorial service

- Swift Peer Review

- Reprints availability

- E-prints Service

- Manuscript Podcast for convenient understanding

- Global attainment for your research

- Manuscript accessibility in different formats

( Pdf, E-pub, Full Text, Audio)

- Unceasing customer service

Track the below URL for one-step submission https://juniperpublishers.com/online-submission.php 